\title{
両側内側縦束症候群の一症例
}

\author{
荻野 貞雄・加藤 功・渡辺 昭司 \\ 高橋 馨子・竹山 勇
}

\section{A Case of Bilateral MLF Syndrome}

\author{
Sadao Ogino, Isao Kato, Syoji Watanabe, \\ Kaoruko Takahashi and Isamu Takeyama \\ (St. Marianna University School of Medicine)
}

\begin{abstract}
Medial longitudinal fasciculus (MLF) plays on important role in the conduction of signals related to the horizontal eye movements.

Here we report a 60 -year-old female with bilateral MLF syndrome caused by multiple sclerosis. In the neurological study, her left eye remained deviated on the left side on straight forward gaze, and convergent eye movements were absent. EOG showed that both eye movement slowed down during nasalward adduction, and were normal during temporalward abduction. No abnormalities were quantitatively recognized in vertical axis. This suggests that the neural tracts of vertical eye movements will be transmitted through routes other than MLF.
\end{abstract}

Key words: MLF syndrome, multiple sclerosis, horizontal eye movements, vertical eye movements

\section{緒言}

MLF-内側縦束は脳幹の傍正中背側を゙綐走す る線維で, その一部は動眼神経核と外転神経核 とを連絡して, 水平方向の眼球運動の重要な神 経路と考えられている. そのなかには, 垂直方 向の眼球運動の神経路と考兄られている経路も 存在しており，サルで両側 MLF 破壊により垂 直方向の眼球運動が障害された報告もみられ る1).

今回, 私共は, 多発硬化症に伴う両側 MLF 症候群の一例を経験したので, 若干の神経耳科 学的検討を加えて報告する.

\section{症例}

60歳, 女性.

主 訴: 複視.

現病歴: 平成元年 7 月 7 日, 会社で仕事中, 突然物が二重に見えることに気づくも，その他 に症状はなく放置していた。症状が改善しない 為, 7 月10日, 複視を主訴に近医内科受診し, 当院第 2 内科を紹介される. 多発硬化症を疑わ れ, 精查加療目的にて 7 月 17 日入院となる. 7 月29日, 当科入院となった.

既往歴, 家族歴：特記すべき事項なし.

血液学的所見, 骨道液所見: 異常なし. 
神経学的所見：意識清明，瞳孔不同なし，対 光反射正常, 眼位は正面視にて左眼球が外転位, 左右眼球運動障害の他は脳神経症状は認めない, 眼底，及び視野に異常なし，病的反射なし，小 脳症状なし，䯣膜刺激症なし。

図 1 は 7 月 17 日入院当日の眼位で, 正面視に て左眼球が外転位, 左眼の内転障害, 右眼の内 転障害を認めるが，上下方向の眼球運動には異 常なかった．輻輳は不能だった．

レントゲン所見：CT, MRI にて異常所見を 認めず。

以下に当科紹介された 7 月 29 日当時の ENG 記録を提示する.いずれも右眼を遮眼し, 左単 眼誘導で記録した。

1 ）追跡眼球運動 (smooth pursuit)

図 2 は追跡眼球運動の DC 記録の原波形で, 左は水平方向, 右は垂直方向で, 上段は右眼, 中段は左眼，下段は指標である. 追跡眼球運動 では, 図 2 に示す通り水平方向三角波刺激で右 眼, 左眼共に内転時に眼球速度の低下が認めら れるが，外転時には異常を認めない。㐬た利得

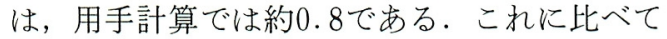
垂直方向（doll's eye 刺激）には, 眼球運動の 障害を認めない，ただし，垂直方向については， 年齢的に随意性の smooth pursuit は artifact の 混在が大きくはっきりしない為, 刺激は眼位を 正面にした状態で頭部を受動的に上下に動かす ことを行ったので，正確にはVOR については 障害がなかったと言える。また，利得は用手計 算では約 0.9 である。

$\mathrm{H}$
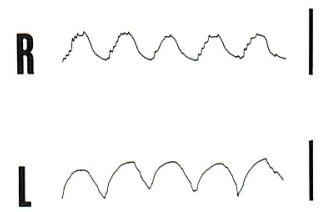

V

$10 \mathrm{~s}$

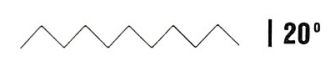

図 2 追跡眼球運動

$\mathrm{H}$ : 水平方向 $\mathrm{V}$ : 垂直方向 $\mathrm{R}$ : 右眼 $\mathrm{L}$ : 左眼

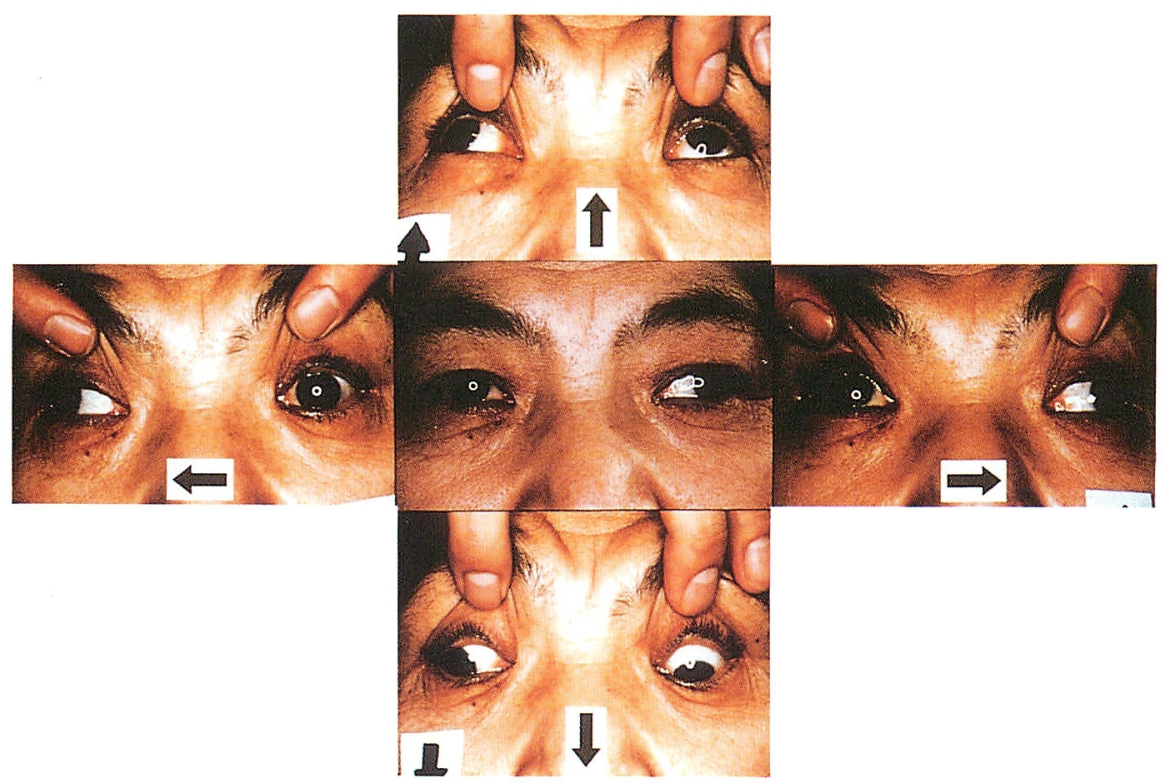

図 1 入院当日の眼位

正面視にて左眼球が外転位で, 左右眼の内転障害を認めるも, 上下方向の眼球運動には異常を認めず. 
2 ）急速眼球運動 (saccade)

図 3 は急速眼球運動の DC 記録の原波形で, 左は水平方向, 右は垂直方向で, 上段は右眼, 中段は左眼, 下段は指標である.急速眼球運動 では図 3 に示寸通り, 右眼, 左眼共に内転時に slowing が認められるが外転時には異常を認め ない.これに比べて垂直方向の眼球運動障害は 認められない.

3) 注 視

(1)水平方向注視

図 4 は水平方向注視の DC 記録の原波形で, 上段は右眼，下段は左眼である. 右眼を遮眼し て左眼で指標を注視している為, 左眼が正中に

H

$$
\text { V }
$$

$10 \mathrm{~s}$

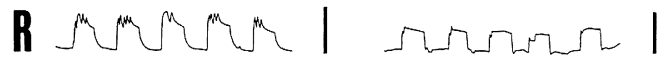
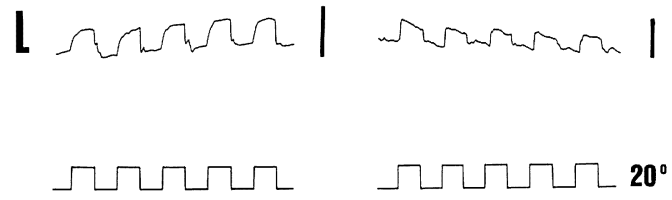

図 3 急速眼球運動

$\mathrm{H}$ : 水平方向 $\mathrm{V}$ : 垂直方向 $\mathrm{R}$ : 右眼 $\mathrm{L}$ : 左眼

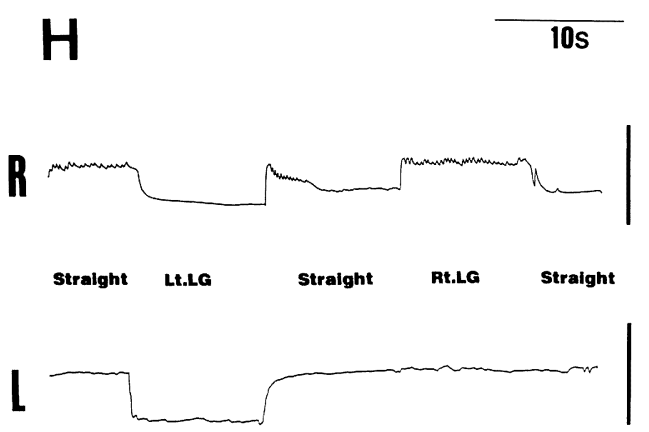

図 4 水平方向注視

$\mathrm{R}$ : 右眼 $\mathrm{L}$ : 左眼
ある時右眼は外転している，この為，正面視に て外転している右眼の右向きの眼振があり, 左 注視時に右眼の内転障害, slowing が認められ, 左眼には左向き眼振が認められる，正中にもど した時, 左眼の内転障害, slowing が認められ る. 外転した右眼はその眼位の保持が不能で徐 々に左方向に偏位している. 次いで右注視時に 左眼の内転障害, slowing, 右眼の右向眼振が 認められる。

(2)垂直方向注視

図 5 は右眼を遮眼した時の垂直方向の注視の DC 記録の原波形で，上段は左眼，下段は右眼 である.水平方向注視に比べて, 眼球運動障害,

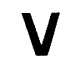

$10 \mathrm{~s}$

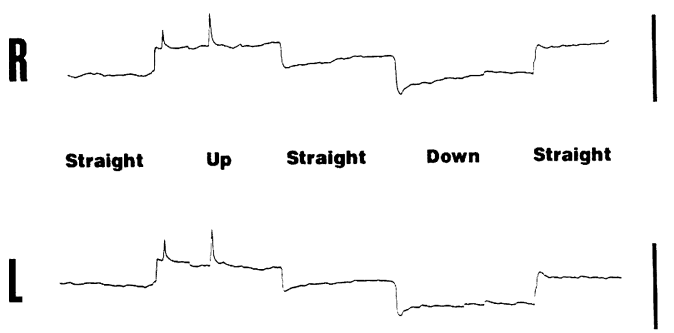

図 5 垂直方向注視

$\mathrm{R}$ : 右眼 $\mathrm{L}$ : 左眼

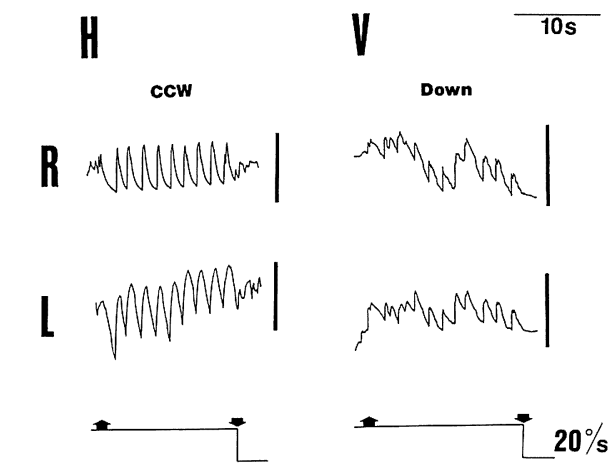

図 6 視運動性眼振

$\mathrm{H}$ : 水平方向 $\left(20^{\circ} / \mathrm{S}\right.$ ステップ, 反時計方向刺激)

$\mathrm{V}$ : 垂直方向（上から下への刺激）

$\mathrm{R}$ ：右眼 $\mathrm{L}$ : 左眼 
及び垂直眼振も認めない。

5 ) 視運動性眼振 $(\mathrm{OKN})$

図 6 は $\mathrm{OKN}$ の DC 記録の原波形で，上段は 左眼, 中段は右眼, 下段は OKN 刺激で, 刺激 速度はいずれも20\% S のステップ刺激である. 左が水平の反時計方向, 右が垂直方向の上から 下上への刺激である。水平方向では, 右眼, 左 眼共に，急速相が眼球の内転方向の時に slowing が認められ，利得は約1.0である。これに 比べて垂直方向には眼球運動障害は認められな い.

\section{経 過}

プレドニンのパルス療法にて, 眼球運動障害 は改善し, 複視も軽快, 9 月10日退院となる.

\section{考察}

MLF-内側縦束は脳幹の傍正中背側を縦走す る線維束で，その一部は，動眼神経核と外転神 経核とを連絡して，水平方向の眼球運動に重要 な役割を果たしている1)。

MLF 症候群は, この神経経路の病変によっ て生じる異常眼球運動であり, 脳幹障害の診断 にとって重要な情報を提供してくれる，その原 因は多種多様であるが，脳血管障害，多発硬化 症等によるものが多いとされている2). 本邦で は脳底動脈傍正中枝血栓症による橋梗塞がもっ とも高頻度にみられ，これによるMLF 症候群 は一側性であり，一方欧米では，多発硬化症に よる MLF 症候群の頻度が高く, 通常は両側性 である3)。多くの MLF 症候群の報告例は一側 性のもので，今回の私共が経験した症例のよう に両側性に障害されているものは希であり，神 経耳科学的に検討された報告例は少ない，

MLF 症候群は側方注視時にみられる障害側 眼の内転障害, 外転した対側眼の外側方向性の 眼振と輻輳可能であることが 3 主徵であり，従 来より Lutz や Cogan らによって以下のように 分類されている. Cogan によれば輻輳障害の 有無によって, 前部型, 後部型, 中間型に分類 され，ある程度輻輳障害が存在するものを前部 型，側方注視もある程度障害されているものを
後部型，その他を中間型としている.しかし， MLF 症候群の中核をなす trias 以外に様々な随 伴症状を伴ら報告例がみられ，今日ではこれら の分類は適当でなく，不要であるといら意見も ある ${ }^{4)}$. MLF は，脳幹被蓋部で橋傍正中部 (PPRF), 外転神経核, その他錐体路, 皮質球 路などと解剖学的にきわめて近接しており，し たがって MLF 障害ばかりでなく PPRF 障害を はじめ多くの合併症を随伴することもあること から考えて, 丸尾4), 松崎5) らの言うように, MLF 症候群ではなく MLF 症候としてとらえ た注うが，良いのではなかららか。

今回の症例で特徴的なことは，図 2 から図 6 に示したよらに, 水平方向では右眼, 左眼共に 内転時に眼球速度の低下, slowing 等, MLF 徵侯がみられ眼球運動障害が顕著であるにもか かわらず垂直方向にはなんら眼球運動障害は認 めなかったことにある. 従来より, MLF は水 平方向の重要な神経路と考兄られているが，両 側 MLF 障害により, 垂直性眼振や, 垂直性眼 球運動障害が認められたといら報告例116)7)がみ られることから，その一部には，垂直方向の眼 球運動の神経路と考えられる経路も存在してる と思われる. Evinger と Fuchus らはサルで, 両側 MLF 破壊により垂直性の眼球運動障害を 報告している1)。すなわち, eccentric fixation の維持が障害され，その修正の為に垂直性の眼 振がみられ, 垂直性 fixaltion の主たる情報は MLF を経由して伝達される, また saccade に 関しては主ではないが VOR, smooth pursuit については MLF が重要な経路である, と述べ ている. 図2でわかるように垂直性の smooth pursuit が保たれていること, 図 5 でわかるよ らに gaze hoding が保たれ, 垂直性眼振はみら れないこと等から, 今回の症例では MLF は広 範囲に障害されず，ある程度 spare されている 可能性も考えられる. 垂直性眼球運動の経路に ついては, 中脳網様帯 (MRF), rostral intestitial nucleus of the MLF (riMLF), 赤核等 が障害され，MLF が spare された症例で垂直 
眼球運動障害が認められたとの報告がみられ る8) 10). また，今まで水平眼球運動の経路と して注目されていた小脳片葉が, 垂直性眼球運 動にも関与している可能性もいわれており, 佐 藤11) は次のように述べている，すなわち，ネ コの片葉のうち rostral zone と caudal zone が 垂直眼球運動の制御を行ない, caudal zone の プルキンエ細胞はy-group 細胞に投射しており， この y-group 細胞は, MLF, ascending tract of Diters, 小脳脚といらルートを通らずに crossing ventral tegmental truct と名付けられ た橋被蓋腹側部のルートを通って動眼神経に投 射する.

以上のことから, 今回の症例に执いては, 両 側の MLF の障害により水平方向では, 右眼, 左眼共に著明な眼球運動障害にもかかわらず, 垂直方向には眼球運動障害がなかったことから, さらに重要な垂直方向の眼球運動の神経路が MLF-内側綎束以外に存在することが示唆され た.

$$
\text { まとめ }
$$

1 ) 多発硬化症に伴う両側 MLF 症候群の一 例を経験した。

2) ENG 記録に扣いて, 水平方向では左右 眼共に内転時に眼球速度の低下, slowing 等, MLF 徵候がみられ眼球運動障害が顕著である にもかかわらず，垂直方向にはなんら眼球運動 障害を認めなかった。

3 ) 垂直方向の眼球運動の神経路が MLF 以 外に存在することが示唆された.

\section{引用文献}

1) Evinger LC, Fuchus $A F$ and Baker R : Bilateral lesions of the medial longitudinal fasciculus in monkeys ; effect on the horizontal and vertical components of voluntary and vestibular induced eye movements. Exp Brain Res 28 : 1 20, 1977.

2) 中里 厚, 里吉営二郎 : MLF 症候群. 脳神経 外科 $5: 3 ; 217 \sim 222,1977$.

3）廣瀬源二郎：MLF 症候群. Clinical Neuroscience $5: 2 ; 114,1987$.

4）丸尾敏夫：核間麻痺. 眼科 $11: 9 ; 716 \sim 722$, 1969.

5）松崎 浩: MLF 症候. 眼科 $20: 357 \sim 369,1978$.

6) 星野守利, 石綿玲子, 小林淳晃, 他：両側 MLF 症候群の 1 例. 埼玉医学会雑誌 $20: 4$; 802 805, 1985.

7）波紫秀厚, 高橋洋司, 小野田祥司, 他: 垂直性 および回旋性眼振を伴った MLF 症候群. 眼紀 32 : 2409 2415, 1981.

8) Halmagyi GH, Evans WA and Hallinann JM : Failure of downward gaze. Arch Neurol 35 : 22 26, 1978.

9) Buttner-Ennever JA and Buttner U : A cell group associated with vertical eye movement in the rostral mesen-cephalic formation of the monkey. Brain Res $151: 31 \sim 47,1978$.

10) Jacobs L, Anderson J and Bender MB : The lesions producing paralysis of downward but not upward gaze. Arch Neurol 28 : 319 323, 1973.

11）佐藤 悠：小脳に上る垂直眼球運動制御. 神経 眼科 $5: 1 ; 10 \sim 15,1988$.

$$
\left(\begin{array}{l}
\text { 別刷請求先 : 荻野貞雄 } \\
\text { T216 川崎市宮前区菅生 2-16-1 } \\
\text { 聖マリアンナ医科大学耳鼻咽喉科学教室 }
\end{array}\right)
$$

